\title{
AN ANALYSIS OF NON PERFORMING ASSETS OF SCHEDULED COMMERCIAL BANKS IN INDIA
}

\author{
Dr. M. Sindhu \\ Assistant Professor, Department of Economics, \\ Sree Kerala Varma college, Thrissur, Kerala, India. \\ DOI: 10.46609/IJSSER.2020.v05i02.010 URL: https://doi.org/10.46609/IJSSER.2020.v05i02.010
}

\begin{abstract}
One of the important problem faced by the banking sector in India is the increase in the amount of Non Performing Assets (NPA). NPA are the assets which will not generate income in the form of interest and principal amount to banks. The NPA affects both the financial system and the economy. The competitiveness, profitability and capital adequacy will be affected by the increase in the NPA of banks. The present study examines the extent of NPA of scheduled commercial banks in India since 1997-98. The analysis showed that the scheduled commercial banks in India faces the problem of NPA. The public sector banks in India have the highest GNPA ratio. In most of the banks the growth rate of NPA is higher than the gross advances. The non priority sector and credit provided to the large borrowers have high NPA. The RBI and government of India have introduced various recovery methods. Among this the recovery through lok adalats, SARFESI Act, Debt Recovery Tribunals etc. are prominent.
\end{abstract}

Keywords: NPA, RBI, Commercial bank, Growth rate, Borrowers

\section{INTRODUCTION}

All advances given by banks are termed as assets as they generate income in the form of interest in instalment. On the basis of performance of loan, it may be classified as standard asset and non performing asset. A standard asset is an asset which generate income to the bank and non performing assets are those assets which has stopped generating income to the bank. An asset becomes a bad loan or non performing asset if interest or principal remains unpaid even after due date. According to World bank estimate of NPA for 121 countries in 2018 shows that the position of India is 27. San Marino (53.02), Ukraine (52.85) and Greece (41.99) are the top three countries having highest NPA. The estimates show that the GNPA of India is 9.46 in 2018. The 


\section{International Journal of Social Science and Economic Research}

ISSN: $2455-8834$

Volume: 05, Issue: 02 "February 2020"

position in 2017 according to the same estimate was 34. This shows that the problem of NPA is increasing in India.

\section{Definition of Non-Performing Assets (NPA):}

An asset, including a leased asset, becomes non-performing when it ceases to generate income for the bank. A 'non-performing asset' (NPA) was defined as a credit facility in respect of which the interest and/ or instalment of principal has remained 'past due' for a specified period of time. An amount due under any credit facility is treated as "past due" when it has not been paid within 30 days from the due date. Due to the improvements in the payment and settlement systems, recovery climate, upgradation of technology in the banking system, etc., it was decided to dispense with 'past due' concept, with effect from March 31, 2001. Accordingly, an asset, including a leased asset, is called NPA when the asset ceases to generate income for the bank. If interest and or instalment of principal amount of loan remain overdue for a period of more than 90 days, of term loan or the account remain 'out of order' in case of overdraft/Cash Credit account or the bills purchased /discounted remain overdue for a period of more than 90 days the account, such accounts will be classified as NPA. Any amount due to the bank under any credit facility is 'overdue' if it is not paid on the due date fixed by the bank. In case of agricultural advance the account is classified as NPA, if the installment of principal or interest thereon remains overdue for two crop seasons for short duration crops. In the case of long duration crop loans, the account will be classified as NPA if the outstanding is overdue for more than one crop season.

\section{Classification of Assets in Indian banking system}

On the recommendation of Gosh Committee on final account for the first time the asset classification for the Indian banking system was introduced in the year 1985. The system of asset classification introduced was known as the 'Health Code System' (HCS). According to this classification bank advances were classified into eight categories ranging from 1 (satisfactory) to 8 (bad and doubtful debt). Till mid eighties, management of NPAs was left to the banks and the auditors. In 1991, the Narasimhan Committee on the financial system suggested to classify the advances into four broad groups like (i) standard assets; (ii) substandard assets; (iii) doubtful assets; (iv) loss assets in accordance with the international standard. In 1992, prudential norms relating to income recognition, asset classification and provisioning were introduced. In 1998, the Narasimhan Committee on Banking Sector Reforms recommended a further tightening of prudential standards in order to strengthen the prevailing norms and bring them on par with evolving international best practices. With the introduction of 90-days norms for classification of NPAs in 2001, the NPA guidelines were brought as par with international standards. For the 


\section{International Journal of Social Science and Economic Research}

ISSN: $2455-8834$

Volume: 05, Issue: 02 "February 2020"

early detection of NPA, a separate form of account known as special mention account was introduced in 2014.

During initial years viz.1985-86, the bankers used to classify the loan accounts as either performing or sick under eight classifications through Health Code System. This system offered information regarding the health of individual advances, the quality of the credit portfolio and the extent of advances causing concern in relation to total advances. As per the system the assets were classified as They are: (i) Satisfactory (ii) Irregular (iii) Sick viable (iv) Sick non viable (v) Advances recalled (vi) Suit filed Accounts (vii) Decreed Debts (viii) Bad and Doubtful Debts. Under the above Health Code System, RBI classified problem loans of each bank into three categories: (iv) \& (v) - Advances with undesirable features (vi) \& (vii) - Advances where suit filed /decrees obtained (viii) - Bad \& Doubtful Debts

International standard of asset classification was introduced in Indian Banking system on the basis of Narasimham committee recommendation on banking sector reform. Accordingly, based on the period, for which the asset remained nonperforming and the realisability of the dues, NPA have been classified into following four types: - (i) Standard Assets: A standard asset is a performing asset. Standard assets generate continuous income and repayments as and when they fall due. Such assets carry a normal risk and are not NPA in the real sense. (ii) Sub- Standard Assets: All those assets (loans and advances) which are considered as nonperforming for a period of 12 months. (iii) Doubtful Assets: All those assets which are considered as non- performing for period of more than 12 months. (iv) Loss Assets: All those assets which cannot be recovered. These assets are identified by the Central Bank or by the Auditors.

\section{TYPES OF NON PERFORMING ASSET}

\section{Gross NPA}

Gross NPAs are the sum total of all loan assets that are classified as NPAs as per RBI guidelines as on Balance Sheet date. Gross NPA reflects the real NPAS and the quality of the loans made by banks. It consists of all the nonstandard assets like as sub-standard, doubtful, and loss assets. Gross NPA equals (Balance in Interest Suspense account + DICGC/ECGC claims received and held pending adjustment + Part payment received and kept in suspense account + Total provisions held). Gross NPA ratio can be calculated as Gross NPAs Ratio = Gross NPAs/Gross Advances

\section{Net NPA}

Net NPAs are those type of NPAs in which the bank has deducted the provision regarding NPAs. Net NPA is obtained by reducing the provisions from Gross NPAs and shows the actual burden of 


\section{International Journal of Social Science and Economic Research}

ISSN: $2455-8834$

Volume: 05, Issue: 02 "February 2020"

banks. Since bank balance sheets contain a huge amount of NPAs and the process of recovery and write off of loans is very time consuming, the provisions the banks have to make against the NPAs according to the central bank guidelines. It can be calculated as Net NPAs = Gross NPAs - Provisions on Gross Advances

\section{Implications of NPA}

Increase in nonperforming assets has adverse effects on the banking sector and the economy. NPA affects the growth and sustainability of banking system. The increase in the amount of NPA is one of the important problem faced by the banks in India. The increase in the amount of NPA led to merging of the banks also. High NPA will divert the concentration of banks from expanding banking business to management of NPA. Increase in NPA will leads to a reduction in interest income, increase in provisioning, reduce their net profit margin and will increase stress on profitability and capital adequacy. Finally, this will affect the competitiveness, reduce the availability of capital for banking business etc. Thus increase in the NPA may finally result into bank failure or merging of banks.

Bank credit has an important role in the growth of an economy, the availability of adequate credit determines the progress of the different sectors in an economy. When the loan taken are not repaid it will affect the credit flow in the banking system. The system of lending-repayingborrowing will be affected. Banks have to seek addition source of funds to meet the requirements of creditors and depositors. Banks will be forced to reduce the loans for new project and on going projects. This will affect GDP growth, industrial output, profit margins and thereby depression in the market. Thus increases in NPA may finally lead to deceleration in economic development.

\section{NPA of Scheduled commercial banks in India}

Gross advance of scheduled commercial bank was Rs.352696 crores in 1997-98 and it increased to Rs. 9266210 crores in 2017-18, with a compound annual average growth of 19.54. But the growth rate of advance during 1997-2007 period was 22.47 and it decelerated to 14.22 per cent during 2008-18 period. Gross NPA of scheduled bank in 19978-98 period was Rs.50815 and it increased with a growth rate of 15.11 per cent to Rs. 1039679 crores in 2018 . The growth rate of GNPA was -1.97 during 1997-2007 period but it increased to 37.41 percent during the period 2008-18. Growth rate of GNPA was more than double of the growth rate of Gross advance during the same period. The average percentage of GNPA as percentage of advance and total assets during 1997-2018 period was 9.8 per cent and 4.4 percent respectively. The trends in GNPA and gross advance of the scheduled commercial banks in India are shown in Figure. 1 and Table. 1 for the period 1997-2018. Compound growth rate of GNPA and GA are given in Table. 4 
International Journal of Social Science and Economic Research

ISSN: $2455-8834$

Volume: 05, Issue: 02 "February 2020"

Figure 1: GNPA ratio of scheduled commercial banks in India

\author{
GNP ratio of SCBs in India
}

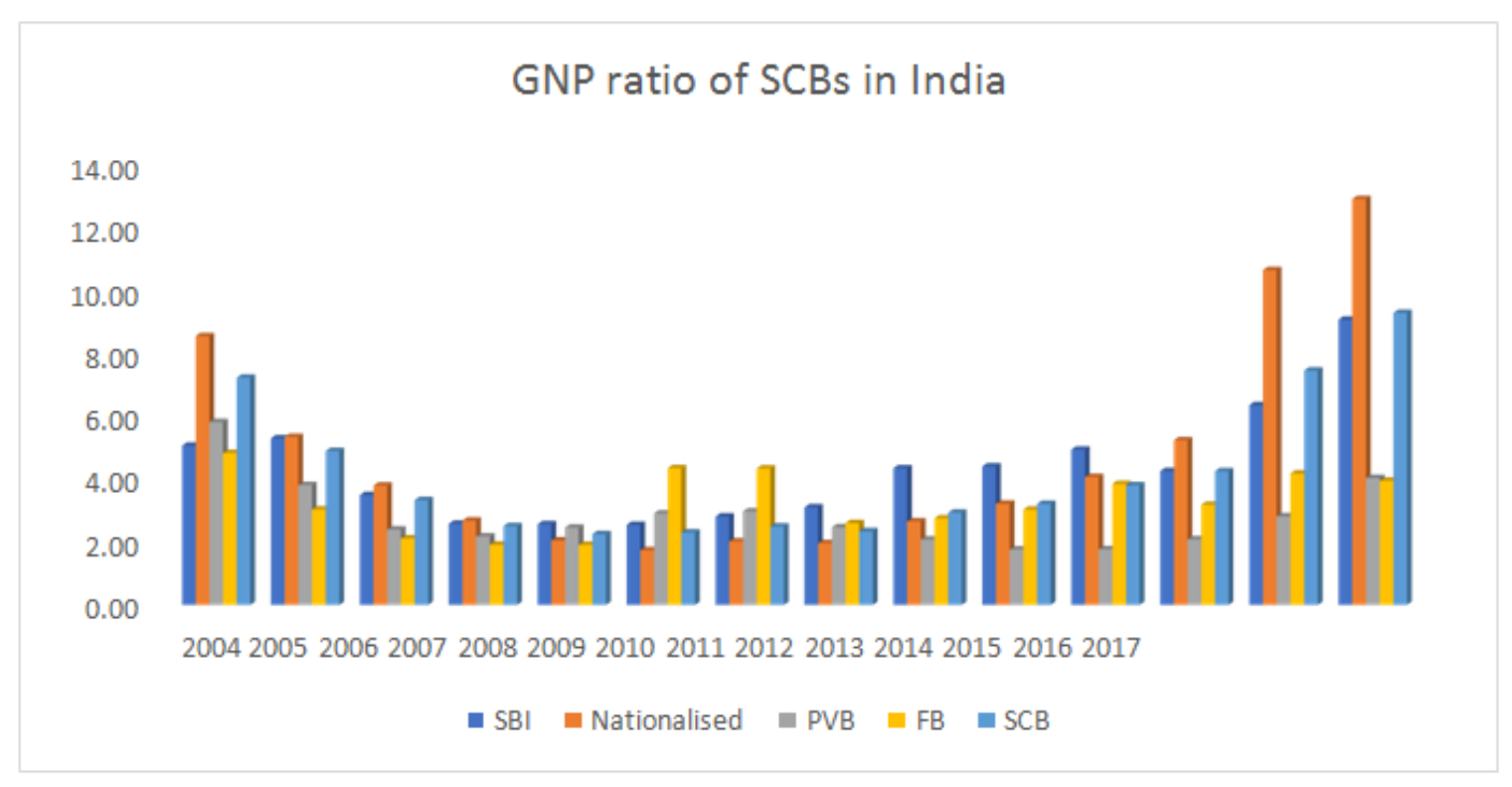

Source: RBI Reports (Various issues)

Table 1: Gross Advance (GA) and Gross Non Performing Assets (GNPA) of scheduled commercial banks in India1997-2018

\begin{tabular}{|c|r|r|r|r|r|r|r|r|}
\hline & \multicolumn{2}{|c|}{$\begin{array}{c}\text { Scheduled Commercial } \\
\text { banks }\end{array}$} & \multicolumn{2}{l|}{ Public sector bank } & \multicolumn{2}{l|}{ Private sector bank } & \multicolumn{2}{l|}{ Foreign Bank } \\
& $\begin{array}{c}\text { Gross } \\
\text { advance }\end{array}$ & GNPA & $\begin{array}{c}\text { Gross } \\
\text { advance }\end{array}$ & GNPA & $\begin{array}{c}\text { Gross } \\
\text { advance }\end{array}$ & GNPA & $\begin{array}{c}\text { Gross } \\
\text { advance }\end{array}$ & GNPA \\
\hline $1997-98$ & 352696 & 325522 & 284971 & 260459 & 11173 & 11058 & 30972 & 29652 \\
\hline $1998-99$ & 399436 & 367012 & 325328 & 297789 & 14070 & 13714 & 31059 & 29492 \\
\hline $1999-00$ & 475113 & 444292 & 379461 & 352714 & 22816 & 22156 & 37432 & 35543 \\
\hline $2000-01$ & 558766 & 526328 & 442134 & 415207 & 31499 & 30086 & 45395 & 43063 \\
\hline $2001-02$ & 680958 & 645859 & 509368 & 480681 & 76901 & 74187 & 50631 & 48705 \\
\hline $2002-03$ & 778043 & 740473 & 577813 & 549351 & 94718 & 89515 & 54184 & 52171 \\
\hline $2003-04$ & 902026 & 862643 & 661975 & 631383 & 119511 & 115106 & 62632 & 60506 \\
\hline $2004-05$ & 1152682 & 1115663 & 877825 & 848912 & 127420 & 123655 & 77026 & 75354 \\
\hline $2005-06$ & 1551378 & 1516811 & 1134724 & 1106288 & 232536 & 230005 & 98965 & 97562 \\
\hline $2006-07$ & 2007413 & 1981237 & 1464493 & 1440146 & 418241 & 414751 & 124677 & 126339 \\
\hline $2007-08$ & 2503431 & 2476936 & 1819074 & 1797401 & 523699 & 518402 & 160658 & 161133 \\
\hline $2008-09$ & 3024652 & 2999924 & 2283473 & 2259212 & 575167 & 575328 & 166012 & 165385 \\
\hline $2009-10$ & 3262079 & 3496720 & 2519331 & 2701300 & 579535 & 632441 & 163213 & 163260 \\
\hline
\end{tabular}


International Journal of Social Science and Economic Research

ISSN: $2455-8834$

Volume: 05, Issue: 02 "February 2020"

\begin{tabular}{|r|r|r|r|r|r|r|r|r|}
\hline $2010-11$ & 3995982 & 4297487 & 3079804 & 3304433 & 723205 & 797544 & 192972 & 195511 \\
\hline $2011-12$ & 4648808 & 5073559 & 3550389 & 3877308 & 871641 & 966403 & 226777 & 229849 \\
\hline $2012-13$ & 5971820 & 5879773 & 4560169 & 4472845 & 1151246 & 1143240 & 260405 & 263680 \\
\hline $2013-14$ & 6875748 & 6735213 & 5215920 & 5101137 & 1360253 & 1342935 & 299576 & 291142 \\
\hline $2014-15$ & 7560666 & 7388160 & 5616718 & 5476250 & 1607339 & 1584312 & 336609 & 327599 \\
\hline $2015-16$ & 8171114 & 7896467 & 5821952 & 5593577 & 1972659 & 1939339 & 376504 & 363551 \\
\hline $2016-17$ & 8476705 & 8116109 & 5866373 & 5557232 & 2266721 & 2219475 & 343611 & 332335 \\
\hline $2017-18$ & 9266210 & 8745978 & 6141698 & 5697350 & 2725891 & 2662753 & 363305 & 351016 \\
\hline
\end{tabular}

Source: RBI Reports (Various issues)

\section{NPA of Public sector banks}

The Gross advance of public sector bank increased from Rs. 284971 crores in 1997 to Rs. 6141698 crores in 2018. This shows a compound growth rate of 18.92 per cent during 1997-2018 period. The gross NPA of public sector bank was Rs. 45653 crores in 1997 and it increased to Rs. 895601 crores in 2018. The growth rate of GNPA was 15.26 per cent during this period. The growth rate of GNPA during 1997-2007 was -3.71 and it increased drastically during 2008-18 period with a growth rate of 41.51 per cent. The average share of GNPA to gross advance and Total assets was 10.6 percent and 4.7 per cent during 1997-2018 period. The GNPA as per cent of gross advances was 16 per cent in 1997-98 and in 2018 it was 14.6 per cent in 2018.

Table 2: Gross NPA as Percentage of Gross advance (GNPA\% GA) of Scheduled commercial banks in India

\begin{tabular}{|l|r|r|r|r|}
\hline & $\begin{array}{r}\text { Scheduled } \\
\text { Commercial } \\
\text { banks }\end{array}$ & $\begin{array}{r}\text { Public } \\
\text { sector }\end{array}$ & Private & $\begin{array}{r}\text { Foreign } \\
\text { banks }\end{array}$ \\
\hline $1997-98$ & 14.4 & 16.0 & 3.5 & 6.4 \\
\hline $1998-99$ & 14.7 & 15.9 & 6.2 & 7.6 \\
\hline $1999-00$ & 12.7 & 14.0 & 4.1 & 7.0 \\
\hline $2000-01$ & 11.4 & 12.4 & 5.1 & 6.8 \\
\hline $2001-02$ & 10.4 & 11.1 & 8.9 & 5.4 \\
\hline $2002-03$ & 8.8 & 9.4 & 7.6 & 5.3 \\
\hline $2003-04$ & 7.2 & 7.8 & 5.0 & 4.6 \\
\hline $2004-05$ & 5.2 & 5.5 & 3.6 & 2.8 \\
\hline $2005-06$ & 3.3 & 3.6 & 1.7 & 1.9 \\
\hline $2006-07$ & 2.5 & 2.7 & 2.2 & 1.9 \\
\hline $2007-08$ & 2.2 & 2.2 & 2.5 & 1.9 \\
\hline $2008-09$ & 2.3 & 2.0 & 2.9 & 4.4 \\
\hline $2009-10$ & 2.5 & 2.3 & 3.0 & 4.4 \\
\hline $2010-11$ & 2.4 & 2.3 & 2.5 & 2.6 \\
\hline $2011-12$ & 2.9 & 3.2 & 2.1 & 2.8 \\
\hline
\end{tabular}


International Journal of Social Science and Economic Research

ISSN: $2455-8834$

Volume: 05, Issue: 02 "February 2020"

\begin{tabular}{|r|r|r|r|r|}
\hline $2012-13$ & 3.2 & 3.6 & 1.8 & 3.0 \\
\hline $2013-14$ & 3.8 & 4.4 & 1.8 & 3.9 \\
\hline $2014-15$ & 4.3 & 5.0 & 2.1 & 3.2 \\
\hline $2015-16$ & 7.5 & 9.3 & 2.8 & 4.2 \\
\hline $2016-17$ & 9.3 & 11.7 & 4.1 & 4.0 \\
\hline $2017-18$ & 11.2 & 14.6 & 4.7 & 3.8 \\
\hline
\end{tabular}

Source: RBI Reports (Various issues)

Bank wise analysis of nationalised banks in India, Table.3, shows that Andhra bank has the highest growth rate of NPA during the last 10 years. This bank recorded a growth rate of 60 percent during 2008-2018 period. It was followed by Punjab and Sindh bank (56 per cent) and Corporation bank (53 per cent). These three banks recorded a growth rate of above 50 per cent. Vijaya bank and Syndicate bank have lowest growth rate (30.36 and 32.59 per cent respectively). Among the nationalised bank other than the SBI group the growth rate of NPA during the period 1997-2018 was 43.22 per cent whereas the growth rate of gross advance was 13.32 per cent.

Table 3: Bank wise GNPA as percentage to Gross Assets (GNPA\%GA) of Nationalised banks in India

\begin{tabular}{|c|c|c|c|c|c|c|c|c|c|c|c|c|c|}
\hline Nationalised Bank & 2008 & 2009 & 2010 & 2011 & 2012 & 2013 & 2014 & 2015 & 2016 & 2017 & 2018 & $\begin{array}{l}\text { CGR } \\
\text { GNPA }\end{array}$ & $\begin{array}{l}\text { CGR } \\
\text { GA }\end{array}$ \\
\hline ANDHRA BANK & 1.08 & 0.83 & 0.86 & 1.38 & 2.12 & 3.71 & 5.29 & 5.31 & 8.39 & 12.25 & 17.09 & 59.89 & 16.28 \\
\hline $\begin{array}{l}\text { PUNJAB AND SIND } \\
\text { BANK }\end{array}$ & 0.74 & 0.65 & 0.63 & 0.99 & 1.65 & 2.96 & 4.41 & 4.76 & 6.48 & 10.45 & 11.19 & 56.33 & 12.90 \\
\hline $\begin{array}{l}\text { CORPORATION } \\
\text { BANK }\end{array}$ & 1.47 & 1.14 & 1.02 & 0.91 & 1.26 & 1.72 & 3.42 & 4.81 & 9.98 & 11.70 & 17.35 & 53.15 & 13.66 \\
\hline $\begin{array}{l}\text { IDBI BANK } \\
\text { LIMITED }\end{array}$ & 1.87 & 1.38 & 1.54 & 1.79 & 2.57 & 3.22 & 4.90 & 5.88 & 10.98 & 21.25 & 27.95 & 47.56 & 8.94 \\
\hline BANK OF BARODA & 1.84 & 1.27 & 1.64 & 1.62 & 1.89 & 2.40 & 2.94 & 3.72 & 9.99 & 10.46 & 12.26 & 47.45 & 17.02 \\
\hline INDIAN BANK & 1.21 & 0.89 & 0.76 & 0.99 & 1.94 & 3.33 & 3.67 & 4.40 & 6.66 & 7.47 & 7.37 & 46.88 & 14.22 \\
\hline $\begin{array}{l}\text { PUNJAB NATIONAL } \\
\text { BANK }\end{array}$ & 2.74 & 1.77 & 1.71 & 1.79 & 3.15 & 4.27 & 5.25 & 6.55 & 12.90 & 12.53 & 18.38 & 45.40 & 14.27 \\
\hline DENA BANK & 2.45 & 2.13 & 1.80 & 1.86 & 1.67 & 2.19 & 3.33 & 5.45 & 9.98 & 16.27 & 22.04 & 45.02 & 13.36 \\
\hline BANK OF INDIA & 1.68 & 1.71 & 3.31 & 2.64 & 2.91 & 2.99 & 3.15 & 5.39 & 13.07 & 13.22 & 16.58 & 45.01 & 15.26 \\
\hline $\begin{array}{l}\text { INDIAN OVERSEAS } \\
\text { BANK }\end{array}$ & 1.63 & 2.54 & 4.71 & 2.71 & 2.79 & 4.02 & 4.98 & 8.33 & 17.40 & 22.39 & 25.28 & 44.68 & 10.99 \\
\hline $\begin{array}{l}\text { ALLAHABAD } \\
\text { BANK }\end{array}$ & 2.01 & 1.81 & 1.71 & 1.80 & 1.91 & 3.92 & 5.73 & 5.46 & 9.76 & 13.09 & 15.96 & 44.35 & 13.12 \\
\hline CANARA BANK & 1.32 & 1.56 & 1.53 & 1.47 & 1.75 & 2.57 & 2.49 & 3.89 & 9.40 & 9.63 & 11.84 & 43.62 & 13.38 \\
\hline $\begin{array}{l}\text { BANK OF } \\
\text { MAHARASHTRA }\end{array}$ & 2.57 & 2.29 & 2.96 & 2.47 & 2.28 & 1.49 & 3.16 & 6.33 & 9.34 & 16.93 & 19.48 & 42.31 & 14.65 \\
\hline
\end{tabular}




\section{International Journal of Social Science and Economic Research}

ISSN: $2455-8834$

Volume: 05, Issue: 02 "February 2020"

\begin{tabular}{|l|c|c|c|c|c|c|c|c|c|c|c|r|r|}
\hline $\begin{array}{l}\text { UNION BANK OF } \\
\text { INDIA }\end{array}$ & 2.18 & 1.96 & 2.25 & 2.37 & 3.16 & 2.98 & 4.08 & 4.96 & 8.70 & 11.16 & 15.73 & 41.48 & 15.18 \\
\hline $\begin{array}{l}\text { ORIENTAL BANK } \\
\text { OF COMMERCE }\end{array}$ & 2.31 & 1.53 & 1.74 & 1.98 & 3.17 & 3.21 & 3.99 & 5.18 & 9.57 & 13.73 & 17.63 & 40.63 & 10.84 \\
\hline UCO BANK & 2.97 & 2.21 & 2.15 & 3.31 & 3.73 & 5.42 & 4.32 & 6.76 & 16.09 & 17.12 & 24.64 & 38.48 & 8.95 \\
\hline $\begin{array}{l}\text { UNITED BANK OF } \\
\text { INDIA }\end{array}$ & 2.70 & 2.85 & 3.21 & 2.51 & 3.41 & 4.25 & 10.47 & 9.49 & 13.26 & 15.53 & 24.10 & 37.50 & 8.80 \\
\hline $\begin{array}{l}\text { CENTRAL BANK OF } \\
\text { INDIA }\end{array}$ & 3.16 & 2.67 & 2.32 & 1.82 & 4.83 & 4.80 & 6.27 & 6.09 & 11.95 & 17.81 & 21.48 & 36.37 & 8.88 \\
\hline SYNDICATE BANK & 2.71 & 1.93 & 2.43 & 2.65 & 2.75 & 1.99 & 2.62 & 3.13 & 6.70 & 8.50 & 11.53 & 32.59 & 14.13 \\
\hline VIJAYA BANK & 1.60 & 1.95 & 2.37 & 2.56 & 2.93 & 2.17 & 2.41 & 2.79 & 6.64 & 6.59 & 6.34 & 30.36 & 13.92 \\
\hline $\begin{array}{l}\text { NATIONALISED } \\
\text { BANKS }\end{array}$ & 2.06 & 1.75 & 2.03 & 1.97 & 2.67 & 3.24 & 4.09 & 5.26 & 10.69 & 12.95 & 14.58 & 43.22 & 13.32 \\
\hline
\end{tabular}

Source: RBI Reports (Various issues)

NPA of private sector banks in India

The GNPA of private sector bank in 1997-98 was Rs.392 crores and it increased to Rs.129335 crores in 2018. During the period 1997-2018 the growth rate of NPA of private sector bank was 24.41. The growth rate of GNPA of private sector bank 1997-2007 was higher than the period 2008-18 period. It was 30.06 and 25.8 per cent respectively. The gross advances of private sector bank were Rs.11173 crores and it increased to Rs.2725891 crores in 2018. During this period the growth rate of advances was 30.08 per cent. The growth rate of advances of private sector banks showed an increase during 1997-2007 period (47.57 per cent) than 2008-18 period (20.35 per cent) The percentage of GNPA to gross advance showed a decline since 2003 to 2015 in the case of private sector banks. During the last two years the share started increasing as shown in Table 2. Among the banks in the private sector YES bank ltd showed a highest growth rate of GNPA during 2008-18 period. Lakshmi Vilas bank, Jammu and Kashmir bank ltd and ICICI banks have the nearly 10 per cent of advance as GNPA in 2018. In the case of private sector bank also the share of GNPA to gross advances shows an increase since 2008.

Table 4: Compound Growth rate of Gross Assets and Gross NPA of scheduled commercial banks in India

\begin{tabular}{|c|c|c|c|c|c|c|c|c|}
\hline & \multicolumn{2}{|c|}{$\begin{array}{l}\text { Scheduled commercial } \\
\text { banks }\end{array}$} & \multicolumn{2}{|c|}{ Public sector banks } & \multicolumn{2}{|c|}{$\begin{array}{l}\text { Private sector } \\
\text { banks }\end{array}$} & \multicolumn{2}{|c|}{ Foreign banks } \\
\hline & $\begin{array}{l}\text { Gross } \\
\text { advance }\end{array}$ & GNPA & $\begin{array}{l}\text { Gross } \\
\text { advance }\end{array}$ & GNPA & $\begin{array}{l}\text { Gross } \\
\text { advance }\end{array}$ & GNPA & $\begin{array}{l}\text { Gross } \\
\text { advance }\end{array}$ & GNPA \\
\hline $\begin{array}{l}1997- \\
2018\end{array}$ & 19.54 & 15.11 & 18.92 & 15.26 & 30.08 & 24.41 & 14.85 & 11.50 \\
\hline $\begin{array}{l}1997- \\
2007\end{array}$ & 22.47 & -1.97 & 20.98 & -3.71 & 47.97 & 30.06 & 18.86 & -0.73 \\
\hline $\begin{array}{l}2008- \\
2018\end{array}$ & 14.22 & 37.41 & 12.56 & 41.51 & 20.35 & 25.80 & 10.80 & 11.58 \\
\hline
\end{tabular}




\section{NPA of foreign banks in India}

GNPA ratio of foreign banks shows a decline over the period since 1997-98. The GNPA ratio declined from 6.4 in 1997-98 to 3.8 in 2017-18 period. Out of 48 foreign banks majority of foreign banks in India showed a decline in the GNPA ratio. The Gross advances and GNPA of foreign banks showed lowest growth rate than other banks. Total GNPA of foreign bank in 2017-18 period was Rs.351016 crores in 2017-18.

\section{Sector wise GNPA of scheduled commercial banks in India}

Sector wise GNPA as percentage of gross Asset for nationalised banks and public sector banks are given below. Table. 5 shows that the highest percentage of NPA is from the non priority sector. The priority sector which accounted 47.1 percent of its assets as NPA in 2003 has declined to 24.8 percent in 2017. In 2017 the percentage of GNPA of non priority sector was 75.2 among the nationalised banks. The public sector has a GNPA ratio of 2.9 percent in 2017.

\section{Table 5: Sector wise GNPA of Nationalised banks in India}

\begin{tabular}{|r|r|r|r|}
\hline & \multicolumn{1}{|l|}{ priority } & \multicolumn{1}{l|}{$\begin{array}{l}\text { Non } \\
\text { priority }\end{array}$} & \multicolumn{1}{l|}{$\begin{array}{l}\text { Public } \\
\text { sector }\end{array}$} \\
\hline 2003 & 47.1 & 51.3 & 1.6 \\
\hline 2004 & 47.7 & 51.1 & 1.1 \\
\hline 2005 & 46.8 & 52.0 & 1.2 \\
\hline 2006 & 51.8 & 45.9 & 2.3 \\
\hline 2007 & 58.6 & 39.5 & 1.9 \\
\hline 2008 & 64.0 & 34.3 & 1.8 \\
\hline 2009 & 59.4 & 40.2 & 0.5 \\
\hline 2010 & 53.8 & 45.4 & 0.8 \\
\hline 2011 & 55.6 & 43.8 & 0.5 \\
\hline 2012 & 47.0 & 51.5 & 1.5 \\
\hline 2013 & 40.2 & 58.9 & 0.9 \\
\hline 2014 & 36.5 & 63.5 & 0.1 \\
\hline 2015 & 34.6 & 65.3 & 0.1 \\
\hline 2016 & 23.2 & 76.8 & 0.4 \\
\hline 2017 & 24.8 & 75.2 & 2.9 \\
\hline Source: RBI Reports (Various issues)
\end{tabular}

Among the public sector banks also the non priority sector has the highest percentage of GNPA. Figure. 2 gives that the share of GNPA of priority sector in 2003 was 47.2 per cent and it declined 
to 20.9 per cent in 2018. In 2018 the share of non priority sector increased to 79.1 percent. The share of public sector in 2018 was 1.9 per cent.

Figure 2: GNPA ratio of Public sector banks in India

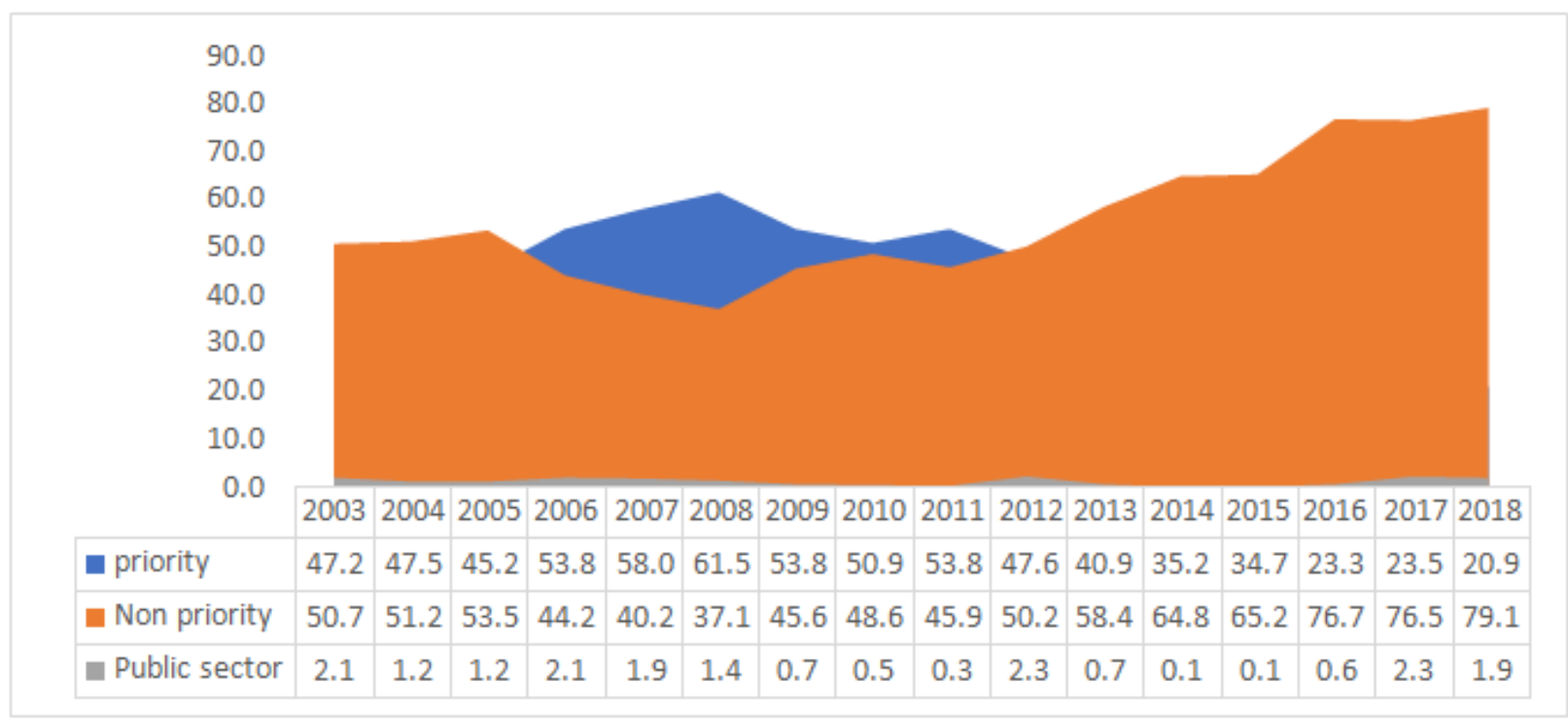

\section{Category wise NPA of scheduled commercial banks}

Gross NPA ratio by different sectors are given in the figure.3. The highest ratios are in the industrial sector. Agriculture sector is in the second position followed by service sector. The GNPA ratio of industrial sector is more than double of the agriculture sector.

Figure 3: GNPA ratio of scheduled commercial banks in India-Sector wise

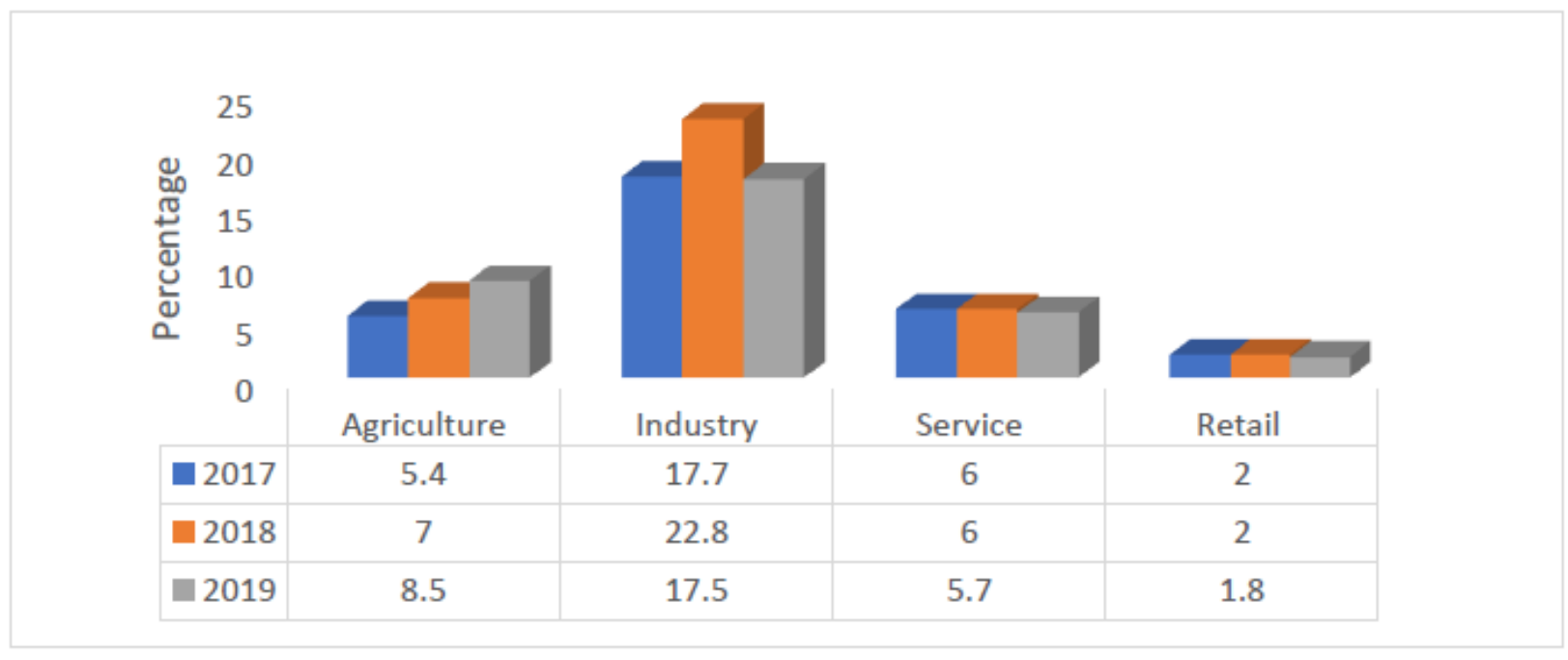




\section{GNPA of Large borrowers from scheduled commercial banks}

The share of large borrowers in the gross advance and GNPA (Figure.4) shows that about 55 per cent of the gross advance is occupied by the large borrowers since 2016. The share of large borrowers in the GNPA is nearly 85 per cent during the period 2016-2019 period.

Figure 4: Gross advance and GNPA of Large borrowers from Scheduled commercial banks in India

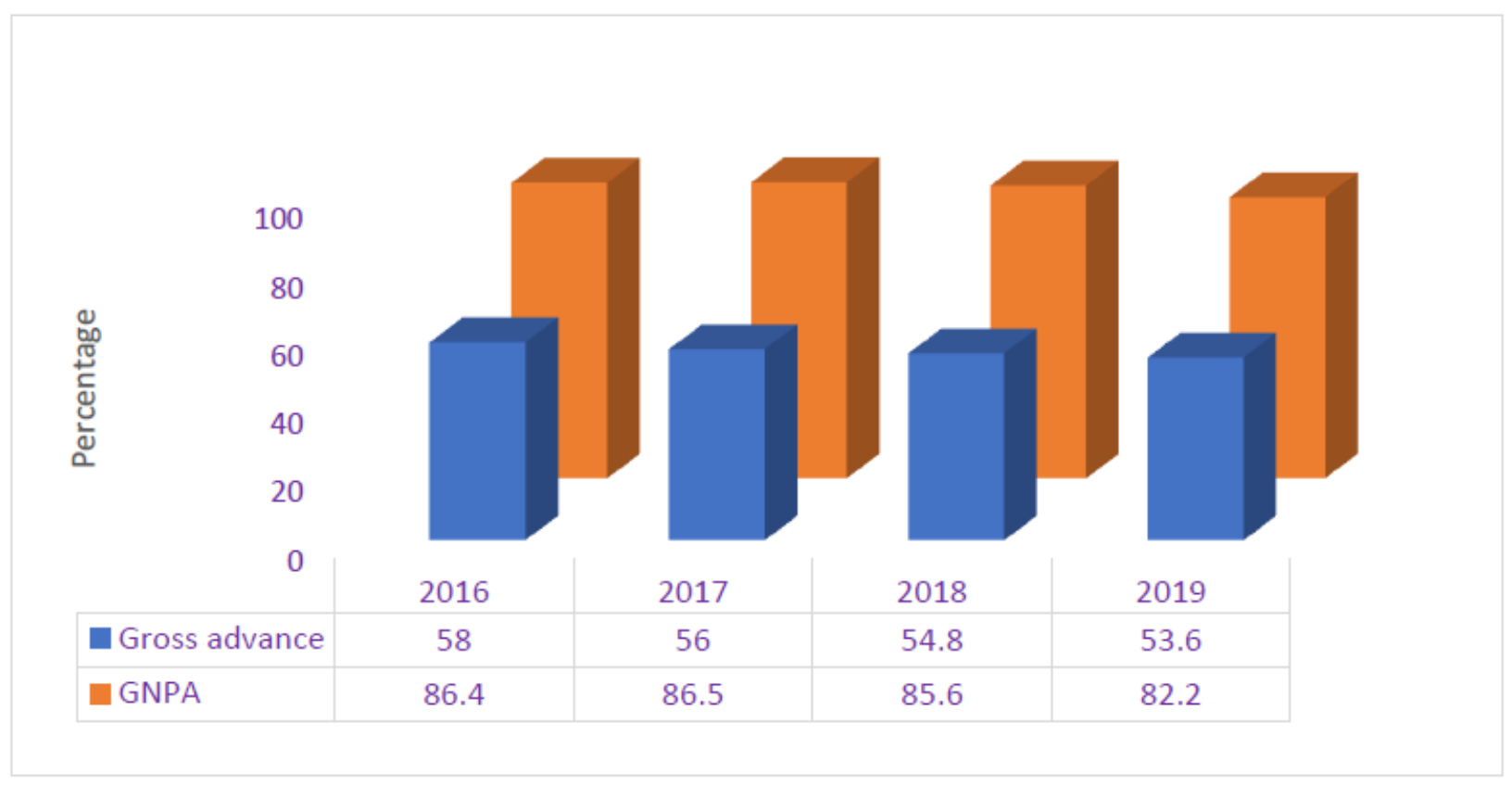

\section{Methods of recovery of NPA}

RBI and government has introduced various schemes, methods and strategies to recover the NPA of various banks. The schemes like one time settlements, compromise settlement was also used as a recovery method. Other recovery measures include the setting up of Debt Recovery Tribunal, Lok adalat, SARFESI Act etc. The important recovery methods of scheduled commercial banks in India is given in Table.6.The highest number of cases was referred in Lok Adalat followed by SARFESI Act. The number of cases referred shows an increase in all the methods as given in the table. During 2012- 15 period the highest recovery is recorded by SARFESI Act. In 2016-17the major share of recovery was done by Debt Recovery Tribunal. 
International Journal of Social Science and Economic Research

ISSN: $2455-8834$

Volume: 05, Issue: 02 "February 2020"

Table 6: NPAs of Scheduled Commercial Banks Recovered through Various Channels

(Rs. In Crores)

\begin{tabular}{|c|c|c|c|c|c|}
\hline & Recovery Channel & $\begin{array}{l}\text { Lok } \\
\text { Adalats }\end{array}$ & DRTs & $\begin{array}{l}\text { SARFAESI } \\
\text { Act }\end{array}$ & Total \\
\hline \multirow[t]{4}{*}{$2012-13$} & No. of cases referred & 840691 & 13408 & 190537 & 1044636 \\
\hline & Amount involved & 6600 & 31000 & 68100 & 105700 \\
\hline & Amount recovered & 400 & 4400 & 18500 & 23300 \\
\hline & $\begin{array}{l}\% \text { of amount involved } \\
\text { and recovered }\end{array}$ & 6.1 & 14.2 & 27.2 & 22 \\
\hline \multirow[t]{4}{*}{$2013-14$} & No. of cases referred & 1636957 & 28258 & 194,707 & 1859922 \\
\hline & Amount involved & 23200 & 55300 & 95300 & 173800 \\
\hline & Amount recovered & 1400 & 5300 & 25300 & 32000 \\
\hline & $\begin{array}{l}\% \text { of amount involved } \\
\text { and recovered }\end{array}$ & 6 & 9.6 & 26.6 & 18.4 \\
\hline \multirow[t]{4}{*}{$2014-15$} & No. of cases referred & 2958313 & 22004 & 175355 & 3155672 \\
\hline & Amount involved & 31000 & 60400 & 156800 & 248200 \\
\hline & Amount recovered & 1000 & 4200 & 25600 & 30800 \\
\hline & $\begin{array}{l}\% \text { of amount involved } \\
\text { and recovered }\end{array}$ & 3.2 & 7 & 16.3 & 12.4 \\
\hline \multirow[t]{4}{*}{$2015-16$} & No. of cases referred & 4456634 & 24537 & 173582 & 4654753 \\
\hline & Amount involved & 72000 & 69300 & 80100 & 221400 \\
\hline & Amount recovered & 3200 & 6400 & 13200 & 22800 \\
\hline & $\begin{array}{l}\% \text { of amount involved } \\
\text { and recovered }\end{array}$ & 4.4 & 9.2 & 16.5 & 10.3 \\
\hline \multirow[t]{4}{*}{$2016-17$} & No. of cases referred & 2152895 & 28902 & 80076 & 2261873 \\
\hline & Amount involved & 105787.1 & 67089.42 & 113099.7 & 285976.2 \\
\hline & Amount recovered & 3803.33 & 16393.08 & 7757.999 & 27954.4 \\
\hline & $\begin{array}{l}\% \text { of amount involved } \\
\text { and recovered }\end{array}$ & 3.595269 & 24.43466 & 6.859436 & 9.775082 \\
\hline
\end{tabular}

Source: RBI Reports (Various issues)

\section{CONCLUSIONS}

One of the important challenge faced by the scheduled commercial banks in India is the increase in the amount of NPA. The analysis shows that the almost all banks in India faces this problem. The growth rate of NPA of all banks shows an increase. The GNPA ratio of public sector banks 
and scheduled commercial banks during 2017-18 was 14.6 and 11.2 per cent respectively. The NPA of private sector and foreign banks have shown a decline in recent years. Majority of the NPA comes from the non priority sector. Among the sectors, industrial sector has the highest NPA. Nearly 85 percent of the loans provided to the large borrowers are in NPA. Some of the important reasons for this increase in NPA may be the deterioration in the asset quality of Indian banks, lack of proper credit monitoring mechanism etc. The bankrupty code introduced in May 2016 is expected to reduce the problem of NPA of banks in India. All public sector banks that was merged in 2019 have high NPA ratio. Thus the increase in NPA will result into the merging or bank failures.

\section{REFERENCES}

Chandan Chatterjee, J. M., (2012) Management of Non- Performing Assets- A Current Scenario. International Journal of Social Science and Interdisciplinary Research, vol.1 (11), 204214.

Prasad and Veena, "NPAs Reduction Strategies for Commercial Banks in India". International Journal of Management and Business Studies. Vol.1 Issue 3, pp. 49-53, 2011 Reserve Bank of India, Financial Stability Reports (Various issue)

WwW.rbi.org

WwW.Worldbank.org 